\title{
Unleashing the immune response against childhood solid cancers
}

\author{
John Anderson \\ UCL Great Ormond Street Institute of Child Health \\ 30Guilford Street \\ London WC1N 1EH \\ j.anderson@ucl.ac.uk
}

\section{Abstract}

Tumor immunotherapy has come to the fore fuelled by impressive clinical responses to checkpoint inhibitor antibodies in a range of adult malignancies, and by the success of CAR T cells targeting adult and pediatric B cell malignancies. Clearly, if appropriately fine-tuned, the immune system has the capability to seek out and destroy cancer. Studies in pediatric solid cancers have not so far shown the therapeutic potential checkpoint inhibitors described in adults cancers and this may reflect fewer tumor associated antigens or different immune evasion mechanisms. One potential approach to overcome these limitations will be combine interventions to undermine immune evasion mechanisms with engineered T cell adoptive transfer.

Abstract word count 107

Text word count 3997

Short running title:. Immune response to solid tumors

3 tables not figures 
The concept that the immune system can be used to recognize and destroy cancers is not new. In the early $20^{\text {th }}$ century new York surgeon William Coley (1862-1936) inspired by his observation of cancer regression in patients recovering from septicaemia, injected cancer patients with live and then dead bacteria. Occasional responses are documented in his records although it is hard now to discern real cancer responses that could be attributed to immune activation. Nonetheless, the concept of cancer immunotherapy was born, and with it the belief that cancer might be inherently foreign to the host and hence amenable of detection and elimination. The degree of general acceptance of this belief has varied over the years but those who have kept the faith and made continuing scientific contributions to the field are to be credited for the resurgence of the field in the last 10 years. In 2013 Science hailed cancer immunotherapy as "breakthrough of the year". What has led to this exponential increase in scientific and clinical trial activity in the field? There are three main areas of scientific and clinical observation that taken together have led to the realization that we have at our disposal new insights and new tools to effect dramatic clinical responses in cancer patients. These are 1) increased understanding of the nature of immune evasion; 2) clinical breakthrough from interventions to overcome immunological checkpoints and 3) the blossoming of technologies for genetic modification of $\mathrm{T}$ cells into potent immune effectors.

\section{Understanding of immune evasion}

A prediction that follows from the theory that cancer can be seen as foreign is that individuals with defects of the immune system should have a higher incidence of cancer. For many years, the lack of experimental or observational evidence that the facts fitted this prediction led to widespread questioning of the underlying assumptions. A number of important breakthroughs have led to wholesale reappraisal. Firstly, in experimental animal models several groups have convincingly demonstrated that combining chemical carcinogenesis in combination with maneuvers to subvert the function of adaptive immunity leads to significant increases in the numbers of tumors [1]. Performing these sorts of experiments in humans is not ethically possible but certain experiments of nature can be observed to gain insight into human immune evasion. Interesting examples include the increased incidence of cancers associated with polymorphic variants diminishing innate immunity, higher incidence of cancer in the immunosuppressed, and the clinical observation of synchronous resurgence of cancer in multiple metastastic sites after long periods of remission. Evasion of immune destruction was adopted as a newly agreed hallmark of cancer in 2011 indicating the acceptance that it is a fundamental component of the mechanism of tumor development in virtually all cancers [2].

The molecular pathways that are integral in immune evasion are also coming into focus. Key mechanisms include TGF-beta, JAK2-STAT3 and IDO pathways, and these converge to create an immunosuppressive tumor microenvironment including for example, high concentrations of inhibitory cytokines (IL-10, IL-17), downregulation or hiding of cell surface danger signals for the immune response [3], polarization of immune effectors toward inhibitory or regulatory pheontypes, and depletion of essential growth factors or amino acids for immune effector cells [4].

These mechanism have been shown to be common in pediatric solid cancers [5]; evidence including the a predominance of immunoinhibitory genes in the transcriptional signature associated with adverse prognosis in neuroblastoma [6], the activation of STAT3 and inhibitory pathways by the oncogenic PAX3-FOXO1A fusion protein in alveolar rhabdomyosarcoma [7], production of TGF- $\beta$ by high grade glioma $[8,9]$ and the inhibitory effects of gangliosides such as GD2 in a number of childhood solid cancers [10]. Immune privilege is the concept that the tumor creates its own "immune-priviledged site; in addition to the above mentioned pathways, there is 
evidence in many cancers for stromal cells and the tumor vasculature acting as an effective barrier to the passage of $T$ cells [11]

A number of trial approaches to target childhood solid tumors using immunotherapy have been developed. Table 1 lists representative trials and the general approaches are detailed below.

\section{Clinical trials targeting immunological checkpoints.}

The clinical responses in adult cancer patients have fed into biomarker discovery programmes, which are now starting to identify the predictive biomarkers of response and provide insights into mechanism of action of these drugs. For example in melanoma trials for Ipilimumab, whole exome sequencing of pre-treatment tumor tissue has identified mutational load and cytotoxic gene expression profile in the tumor environment to be correlated with clinical benefit [12]. Response rates to PD1/PD-L1 pathway blockade similarly correlate with mutational burden and the presence of tumor-reactive lymphocytes; but the relationship between expression of the PD-L1 (a possible marker for activity of the pathway) and response is less clear; ie. correlation with response in some series but not others. The reason for this variation in the literature probably reflects the fact that some cancers appear to have deregulated PDL1 in tumor cells as an oncogenic event (eg secondary to genomic amplification) whereas in other cancers its expression is driven by a pro-inflammatory cytokine environment. In the latter scenario, some cancers with naturally occurring responder T cells might have low PD-L1 in resting state due to other mechanisms of immune evasion, but become PD-L1 bright following a pro-inflammatory immunotherapy, by an effect known as "adaptive immune resistance" in which the tumor protect itself by inducing PD-L1 in response to inflammatory cytokines and especially Interferon gamma [13]. Tumors showing adaptive immune resistance are potentially highly responsive to PD-L1 blockade as a component of a combination treatment. Taken together, a strong consensus has developed from the adult oncology field that response to checkpoint inhibitors as single or combination agents correlates very strongly with mutational burden, the presence of tumor-reactive tumor infiltrating lymphocytes, and a cytotoxic transcriptional signature. These three factors are closely related because mutational burden is directly related to neoantigen frequency. A tumor neoantigen is defined as a mutated amino acid sequence specific for a tumor cell, which can be recognized by cells of the adaptive immune system. In the case of T cells this occurs through the normal pathways of intracellular processing of endogenous proteins, which leads to peptides with high affinity for the binding pocket of MHC molecules to thereby be "presented" in a form that can be recognized by the T cell receptor. As the locations of mutations are entirely unrelated to putative $\mathrm{MHC}$ binding, whether a mutation is within a peptide fragment that happens to have sufficiently high affinity for self MHC-I to be displayed, is entirely a matter of chance, but the greater the number of tumor mutations, the greater the possibility that a neoantigen will be displayed [14].

Childhood cancers have significantly lower mutational frequency than adult epithelial cancers that generally arise as a result of DNA damage due to environmental exposures [15]. Does this imply that there will be much lower responses to the checkpoint inhibitors? So far the data from trials suggest that this is the case [16]. However there are exceptions including Hodgkin disease where response rates are high, possibly reflecting the presence of $T$ cell responses against shared viral antigens [17], and rare childhood cancers with very high mutational burden, for example high grade glioma with a hyper-mutator phenotype [18]. The availablility of checkpoint inhibitor antibodies should also lead to a clinical trial re-evaluation of vaccine trial 
approaches that were previously unsuccessful in pediatrics but might shown more effect when combined with immune-modulation.

\section{Adoptive $T$ cell transfer and Engineering a $T$ cell response}

The principle that infusion of tumor reactive $T$ cells can effect rejection of vascularized solid tumors, including brain metastases was initially demonstrated using infusions of tumor infiltrating lymphocytes, especially in melanoma studies. Melanoma has a very high mutational load and the tumor antigen specificities of oligoclonal populations of TILs is emerging through studies utilizing next generation sequencing technologies $[19,20]$. A vital new principle from the TIL studies is that conditioning chemotherapy prior to infusion of $T$ cells greatly increases $T$ cell proliferation and survival within the tumor microenvironment, as well as directly contributing to survival [21]. The mechanism is likely to be multifactorial and probably involves conversion of the tumor microenvironment from anti to pro-inflammatory, induction of immunogenic cell death, depletion of regulatory immune cells, and promotion of danger signals from the host microbiome [22].

Engineering of $T$ cells provides one possible solution to the lack of naturally occurring $\mathrm{T}$ cell responses in most childhood cancers. Two broad approaches are the genetic modification of a $T$ cell population with a $T$ cell receptor (TCR) recognizing a tumor associated antigen (TAA), or with a Chimeric Antigen Receptor (CAR). TCR transfer has not been evaluated extensively in childhood solid cancer, largely because of lack of appropriate TAAs. CARs combine - within a single molecule - the antigen binding domain of a monoclonal antibody linked via a transmembrane sequence to primary and secondary stimulation domains that mimic potent T cells stimulation [23]. In this way, through transduction of a patient's T cells with CAR, a large T cell population can be redirected towards a cell surface tumor associated antigen leading to potent $T$ cell effector function only in the presence of the tumor [21, 24, 25]. Because the response is driven by antibody, it is MHC-unrestricted and can be fine-tuned for potent responses. Moreover, through modulation of the intracellular signalling of the CAR, maximal $T$ cell responses can be optimized. The ideal $T$ cell response will lead to cytotoxicity but also proliferative response and production of proinflammatory cytokines resulting in sustained memory responses, leading to sustained cancer regression.

In the last 10 years many of the rules concerning optimal CAR T cell design have been learned from experience of treating patients with B cell malignancies in which CD19 has been identified as a very effective target antigen [25-27]. It has been found that second generation endodomains containing CD3 zeta as well as a costimulatory domain are optimal; and that CD28 provides potent activation, whilst TNF superfamily domains such as 41BB or OX40 lead to slower but more sustained responses. It has been established that conditioning of the patient with chemotherapy drugs such as fludarabine and cyclophosphamide (Flu/Cy) greatly improved T cell engraftment, and that the combination is more effective that cyclophosphamide alone [28]. Hence in acute B cell leukaemia trials using second generation CD19 CAR T cells and conditioning of patients with $\mathrm{Flu} / \mathrm{Cy}$, unprecedented complete response rates of 80$90 \%$ have been described in patients with chemotherapy-resistant disease [25].

Encouraged by the results of the leukaemia studies, several groups have run trials using second generation CAR T cells in solid cancer in which equivalent lymphodepleting conditioning has been given. Despite good antigen expression in the tumor and good apparent functionality in vitro, these CAR T studies have not led to significant regression of solid cancers [29-31] .

\section{Inhibitory cells of the tumor microenvironment}

The term myeloid derived suppressor cells (MDSC) is used to describe cells invariably found both in the blood and intratumorally in cancer patients and tumor-bearing 
animals. Several subsets in humans have been proposed, with a consensus phenotyping of HLA-DR negative CD33 positive cells being subdivided into MDSC of a more granulocytic lineage (CD15) or monocytic lineage (CD14) [32], the latter associated with production of inhibitory cytokines, arginase and iNOS [33]. MDSC function by a number of mechanisms including depletion of the amino acids $L$-arginine and L-cysteine needed for $T$ cell function [34, 35]. The depletion results from production of the enzymes arginase and inducible nitric oxide synthase-2 (iNOS2) consequent to local inflammatory cytokines. ARG and iNOS convert arginine to metabolites ornithine/urea and nitric oxide/citrulline respectively, which leads to downregulation of CD3- $\zeta$ component of the T cell receptor and loss of $T$ cell function. MDSC also produce high concentrations of TGF- $\beta$, which polarizes T cells toward a regulatory phenotype (regulatory $T$ cells, or Treg) characterized by expression of FOXP3 in CD4 cells. Tregs in the tumor environment in turn inhibit effector functions of cytotoxic and helper T cells [36-38]. COX2 expression has been documented within MDSC in both mouse and humans and appears to be a targetable molecule to inhibit MDSC function [39, 40]. Multiple lines of evidence have correlated the presence of MDSC with aggressive phenotype, advanced stage, resistance to immune therapies, and poor prognosis in many cancer types [41-43]. Other tumor infiltrating stromal cells may play important roles in immune evasion. However tumor infiltrating macrophages (M2 macrophages), which play an important role in promoting tumor growth and angiogenesis, may have immune suppressive properties and can be difficult to distinguish from MDSCs. Several other stromal cell types have been identified as protecting tumors from immune attack including tumor associated fibroblasts, which appear to have a functional role of chemoattracting $T$ cells to themselves and away from the areas of transformed cells in the tumor niche.

Neuroblastoma as a model disease for strategies to overcome the inhibitory tumor microenvironment

Neuroblastoma is a childhood tumor where some of the pathways controlling the mechanisms of immune evasion have been carefully worked out, providing an opportunity for immune targeting in combination therapies, for example with gene modified T cells or vaccines. A 14 gene signature derived from expression array analysis of neuroblastoma tumors associated with poor prognosis, which was validated on independent data sets, contains 5 genes reflecting the tumor microenvironment (CD14, CD33, IL-10, CD16, IL-6R) [6]. Collectively these genes suggest activation of inhibitory cytokine pathways within myeloid cells (CD14, CD33) within the tumor, for example activation of a STAT3-IL-6-IL-10 axis as has been described previously in neuroblastoma [44-46]. MDSC have been shown to be integral to neuroblastoma tumor growth. Neuroblastoma patients $[47,48]$ and tumors have heavy infiltration of myeloid cells [49] which produce arginase and iNOS [50] through an IL-6/STAT3 pathway which inhibits effector $T$ cells function and drives production of regulatory $T$ cells through production of inhibitory cytokines IL-10 and TGF- $\beta$.

Other lines of evidence point to multiple pathways by which neuroblastoma avoids immune detection. Neuroblastoma cells characteristically have very low expression of $\mathrm{MHC}$ class I [3]. They are known to secrete a number of factors to contribute to immune evasion; including soluble form of MICA/MICB, the receptors for the NK cell and T cell receptor NKG2D; these soluble forms acting as receptor antagonists [51, 52].

Approaches for Targeting Myeloid derived suppressor cells in combination studies with adoptive transfer of tumor-reactive T cells.

MDSC have been shown to be inhibitory to the function of CAR T cells [50,53]. Several therapeutic approaches have been proposed for blocking function, reducing numbers 
of MDSC, and direct cytotoxicity. Such therapeutics could be used in combination treatments with adoptively transferred $T$ cells or other immunotherapies and so could represent a novel approach to target mutationally quiet pediatric solid cancers (Table 2).

\section{Blockade of MDSC function}

Sunitinib is a multi-target receptor tyrosine kinase inhibitor that abrogates a number of intracellular signaling pathways including those leading to activation of the STAT3 transcription factor. As well as its direct anti-cancer effects, sunitinib has been shown to decrease function and numbers of MDSC and regulatory T cells in cancer patients [43] and in preclinical models and to be synergistic with immunotherapy [54]. Sunitinib has also shown synergy with tumor irradiation to decrease intratumoral MDSC number and function [55]. In patients treated with sunitinib there has been documented expansion of intratumor lymphocytes and decrease in MDSC [56] as well as decrease in circulating MDSC and regulatory T cells [57]

Arginase production by MDSC is a central mechanism for their suppressive functions. Inhibitors of arginase are being developed and entering early phase evaluation in adult cancer patients. A number of existing drugs also inhibit arginase and other suppressive pathways in MDSC and could be redeployed as combination agents with immunotherapy. Nitroaspirin is an aspirin molecule covalently linked to nitric oxide and is an inhibitor of both iNOS and ARG [58]. It has an acceptable toxicity after trial in diabetes but there is no previous clinical trial experience in cancer. The COX-2 pathway is known to be targetable in neuroblastoma [59, 60]. COX-2 has been proposed to be a mechanism of arginase expression in MDSC through production of prostaglandin E2 [61-64]. COX-2 inhibition can be achieved pharmacologically by a number of agents but the greatest experience is with celecoxib and there is emerging clinical data for its potential to inhibit MDSC and function in combination with immunotherapy [40,62, 65-67]. Another potential inhibitor of prostaglandin signaling is sildenafil, which targets PDE-5 in MDSC and has been shown to augment antitumor immunity [68-70].

A further naturally occurring compound curcumin, which is a component of turmeric, has a number of biochemical properties including inhibition of COX2, which is thought to be mediated by inhibition of JAK2/STAT3 signaling [71, 72], and leads to differentiation of immature myeloid cells and enhanced immunotherapy in murine [73] and human $[74,75]$ tumor models. Curcumin, has excellent safety profile and has been used in pediatric cancer patients [76] but its pharmacodynamics for MDSC suppression has not been described. Indoleamine 2:3 dioxygenase is produced by MDSC as well as tumor cells and has multiple immune-inhibitory functions that appear to stem from tryptophan catabolism; so far however there has been limited success in translating IDO inhibitors into the clinic [77].

\section{Decrease of MDSC numbers.}

It has been recognized that vitamin $A$ is an essential factor of the differentiation of immature to mature myeloid cells [78, 79], and the use of vitamin A analogue All trans retinoic acid (ATRA) in acute promyelocytic leukemia mirrors this differentiation function. In animal studies administration of ATRA leads to decrease in MDSC numbers due to their differentiation into mature proinflammatory myeloid cells [80-82]. Indeed, use of $1 \mu \mathrm{M}$ ATRA to differentiate them into dendritic dells was one included in one of the early studies that defined human MDSC in cancer patients [83]. However, the role of ATRA on MDSC numbers has not been evaluated in human studies, and there are theoretical concerns regarding the ability of ATRA to induce regulatory T cells 
[84]. The excellent safety profile and plentiful experience of ATRA in pediatric cancer studies make it an attractive agent to investigate in combination with adoptive $T$ cell transfer.

Another agent with intriguing MDSC differentiating properties is Polyphenon- $E$ a component of green tea. Importantly, its function has been demonstrated in neuroblastoma models [47, 48]. However, dosages and scheduling needed for effective combination therapies in humans have not yet worked out. Similarly, withaferin $A$, derived from withania root extract, has anti tumor activity which is through to be derived from STAT3 inhibition and tumor microenvironmental effects $[85,86]$. Studies to determine immunomodulation in clinical studies are warranted.

A number of small molecule inhibitors and antibodies targeting the macrophage colony stimulating factor-1 (CSF-1) have been developed and evaluated in early phase trials. MDSC and tumor infiltrating macrophages express CSF-1 suggesting a potential combination approach with $T$ cell transfer and other immunotherapies [87].

\section{Cytotoxic killing of MDSC}

A number of approaches have been suggested for targeting these cells through their cytotoxic elimination or inhibition of their key functional pathways. Markers of immature myeloid cells such as CD33 could potentially be targeted with antibody or CAR T cells to decrease MDSC numbers in the tumor. Such an approach could be envisaged in combination with an immunotherapy targeting of a tumor antigen. Several antibodies or antibody/drug conjugates such as Gemtuzumab ozogamicin have been evaluated in AML and could potentially be investigated for their ability to kill MSDCs [88]. However lysis of normal myeloid cells might cause unacceptable toxicity or undermine functionally important cells for immunotherapy responses. Use of CAR T cells jointly targeting tumor antigen and myeloid antigen such as CD33 remains a possibility albeit with risk of toxicity through normal myeloid inhibition. Use of TRAIL targeting antibodies has been suggested due to the high expression of TRAIL receptor on MDSC [89].

Hitherto, clinical studies with adoptively transferred T cells have focused on the use of lymphodepleting agents such as fludarabine, which has limited effect on myeloid cells, and cyclophosphamide which has been shown to increase MDSC numbers [90-93]. Alternative chemotherapies which are toxic to MDSC as well as lymphodepleting, such as gemcitabine [94, 95] and 5-fluorouracil (5-FU) [96] could be considered as conditioning agents. There is contrary data on 5-FU with one study suggesting it increases MDSC function [97]. However there is no previous published experience of the use of gemcitabine for conditioning adoptive cell transfer in pediatrics and doses would need to be extrapolated from adult studies, for example using Gemcitabine with fludarabine in reduced intensity conditioning [98].

\section{Use of checkpoint inhibitors.}

Antibodies blocking the PD1:PD-L1 pathway might inhibit some of the functions of MDSC by blocking the PD-L1 ligand, which is present on tumor infiltrating myeloid cells [99], and thereby preventing inhibitory signaling in the T cells via PD1. Blockade of CTLA-4, for example through use of Ipilimumab, might abrogate function of MDSC in at least 2 ways: by interfering with engagement of CTLA-4 on T cells by CD80 and CD86 on MDSC, and by direct cytotoxicity of regulatory $T$ cells that are likely to be present in the tumor environment due to the TGF- $\beta$ produced by MDSC [100]. Interestingly responses to ipilimumab in melanoma patients have been shown to correlate with decrease in circulating MDSC [101, 102].

\section{Improve entry of $T$ cells into tumors}


Interference with chemokine signaling: Evidence from adult malignancies such as pancreatic adenocarcinoma has identified mechanisms to concentrate lymphocytes in the vicinity of tumor stromal cells and prevent infiltration into the areas dense in malignant cells [11]. In pancreatic ductal adenocarcinoma and other tumors, tumor associated fibroblasts attract CXCR4 expressing $\mathrm{T}$ lymphocytes through upregulation of CXCL12, leading to a rim of T cell surrounding the tumor [103]. CXCL12 is also known to be a key chemokine for attracting MDSC into the tumor by a COX-2/PGE2 mechanism $[65,104]$. Disruption of the interaction with the drug Plerixafor leads to $T$ cell infiltration, and its use in combination with anti-PD1 antibody leads enhances tumor eradication in a mouse model [103]. Neuroblastoma stromal and vascular structures are known to express high levels of CXCL12, with weak expression in neuroblasts [105] and CXCL12 homing appears to be key for neuroblastoma metastasis [106].

Immunocytokines: Delivery of an inflammatory cytokine to the tumor niche through linkage to an antibody has the potential to achieve high functional concentrations at the tumor site with the avoidance of systemic toxicity [107]. One approach of interest in neuroblastoma is to effect local delivery of IL-2 for example by combination with the L19 antibody, which targets an alternatively spliced domain of fibronectin that is cancer specific and found in most solid tumors, and hence will localize to the extracellular matrix within the tumor niche. Phase I testing in adults by repeated iv infusion reveals significantly less toxicity than is observed with IL-2, and with evidence of clinical activity in renal cell carcinoma [108]. An immunocytokine comprising humanized ch14.18 anti GD2 antibody fused with IL-2 also has a good safety and toxicity profile, with some evidence of activity in neuroblastoma and could be used to deliver local IL-2 in combination with GD2-CAR T cells in view of the very high target antigen density in this cancer [109].

Other approaches: A large number of other theoretical approaches to decrease MDSC number of functionality in the tumor environment could be considered; for example use of hyperbaric oxygen to decrease hypoxic drive, MEK inhibitors to inhibit pathways in both MDSC and tumor cells

\section{Concluding remarks}

Pediatric solid tumor oncologists should be encouraged by the successful experience of immune checkpoint inhibitor antibodies in adult solid cancers, and adoptive transfer of tumor infiltrating lymphocytes in melanoma, or engineered T cells in leukemia. These studies have shown us respectively, that immune evasion can be overcome, that $T$ cells have the potential to induce the lasting regression of solid vascularized tumors, and that engineering of $\mathrm{T}$ cell responses is safe and feasible. Moreover childhood cancers have a range of potential targets on the cell surface (table 3 ) that are ripe for therapeutic exploitation. 
Table 1. Representative recent or current clinical trials in pediatric patients outlining the range of therapeutic approaches being developed.

\begin{tabular}{|c|c|c|}
\hline Trial Title & Description & $\begin{array}{l}\text { Clinical } \\
\text { trials.gov ID }\end{array}$ \\
\hline \multicolumn{3}{|l|}{ Antigen-targeting antibodies } \\
\hline $\begin{array}{l}\text { CH14.18 } 1021 \text { Antibody and IL2 After Haplo SCT in } \\
\text { Children With Relapsed Neuroblastoma }\end{array}$ & $\begin{array}{l}\text { Antibody and cytokine in allogeneic } \\
\text { setting }\end{array}$ & NCT02258815 \\
\hline $\begin{array}{l}\text { Hu14.18-Interleukin-2 Fusion Protein in Treating Young } \\
\text { Patients With Recurrent or Refractory Neuroblastoma }\end{array}$ & Immunocytokine & NCT00082758 \\
\hline $\begin{array}{l}\text { Monoclonal Antibody 3F8 and Sargramostim in } \\
\text { Treating Patients With Neuroblastoma }\end{array}$ & $\begin{array}{l}\text { Anti-GD2 antibody (MSKCC group) } \\
\text { in combination with GM-CSF }\end{array}$ & NCT00072358 \\
\hline $\begin{array}{l}\text { Dinutuximab in Combination With Sargramostim in } \\
\text { Treating Patients With Recurrent Osteosarcoma }\end{array}$ & $\begin{array}{l}\text { Anti-GD2 antibody in combination } \\
\text { with GM-CSF }\end{array}$ & NCT02484443 \\
\hline \multicolumn{3}{|l|}{ Cytokine based therapies } \\
\hline $\begin{array}{l}\text { Pilot Study of Zoledronic Acid and Interleukin-2 for } \\
\text { Refractory Pediatric Neuroblastoma }\end{array}$ & $\begin{array}{l}\text { Cytokine and agent to boost innate } \\
\gamma \delta \text { lymphocytes }\end{array}$ & NCT01404702 \\
\hline \multicolumn{3}{|l|}{ Immune checkpoint targeting } \\
\hline $\begin{array}{l}\text { Pilot Study of Nivolumab in Pediatric Patients With } \\
\text { Hypermutant Cancers }\end{array}$ & $\begin{array}{l}\text { PD (L)1 pathway blocking antibody } \\
\text { for mutation-high gliomas }\end{array}$ & NCT02992964 \\
\hline $\begin{array}{l}\text { A Single-Arm Study to Evaluate the Safety, Tolerability, } \\
\text { Pharmacokinetics, Immunogenicity, and Preliminary } \\
\text { Efficacy of MPDL3280A (Anti-PD-L1 Antibody) } \\
\text { in Pediatric and Young Adult Participants With } \\
\text { Solid Tumors }\end{array}$ & $\begin{array}{l}\text { PD (L)1 pathway blocking antibody } \\
\text { for solid tumours }\end{array}$ & NCT02541604 \\
\hline $\begin{array}{l}\text { Enoblituzumab (MGA271) in Children With B7-H3- } \\
\text { expressing Solid Tumors }\end{array}$ & $\begin{array}{l}\mathrm{B} 7-\mathrm{H} 3 \text { is member of the } \mathrm{B} 7 \text { familiy } \\
\text { with homology with PD-L1 }\end{array}$ & NCT02982941 \\
\hline $\begin{array}{l}\text { Pembrolizumab in Treating Younger Patients With } \\
\text { Recurrent, Progressive, or Refractory High-Grade } \\
\text { Gliomas, Diffuse Intrinsic Pontine Gliomas, or } \\
\text { Hypermutated Brain Tumors }\end{array}$ & $\begin{array}{l}\text { PD }(L) 1 \text { pathway blocking antibody } \\
\text { for brain tumours }\end{array}$ & NCT02359565 \\
\hline \multicolumn{3}{|l|}{ Vaccine -based studies } \\
\hline $\begin{array}{l}\text { A Pilot Study of Autologous T-Cell Transplantation } \\
\text { With Vaccine Driven Expansion of Anti-Tumor Effectors } \\
\text { After Cytoreductive Therapy in } \\
\text { Metastatic Pediatric Sarcomas }\end{array}$ & $\begin{array}{l}\text { Using ex vivo expanded autologous } \\
\text { lymphocytes with a vaccine to boost } \\
\text { effector cell function }\end{array}$ & NCT00001566 \\
\hline $\begin{array}{l}\text { A Pilot Study of Tumor Cell Vaccine for High-risk } \\
\text { Solid Tumor Patients Following Stem Cell } \\
\text { Transplantation }\end{array}$ & $\begin{array}{l}\text { Using the setting of resetting the } \\
\text { immune system following transplant } \\
\text { to vaccinate agasint tumour } \\
\text { antigens }\end{array}$ & NCT00405327 \\
\hline $\begin{array}{l}\text { Dendritic Cell Vaccine Therapy With In Situ Maturation } \\
\text { in Pediatric Brain Tumors }\end{array}$ & $\begin{array}{l}\text { Vaccine approach using immature } \\
\text { DC }\end{array}$ & NCT01902771 \\
\hline $\begin{array}{l}\text { Vaccine Trial for Clear Cell Sarcoma, Pediatric Renal } \\
\text { Cell Carcinoma, Alveolar Soft Part Sarcoma and } \\
\text { Children With Stage IV Melanoma }\end{array}$ & $\begin{array}{l}\text { Vaccine made from autologous } \\
\text { tumour cells and GM-CSF }\end{array}$ & NCT00258687 \\
\hline $\begin{array}{l}\text { Therapy to Treat Ewing's Sarcoma, } \\
\text { Rhabdomyosarcoma or Neuroblastoma }\end{array}$ & $\begin{array}{l}\text { Using autologous tumour cells as } \\
\text { vaccine }\end{array}$ & NCT00923351 \\
\hline \multicolumn{3}{|l|}{ Cell therapy } \\
\hline $\begin{array}{l}\text { Haploidentical Transplant With NK Cell Infusion for } \\
\text { Pediatric Acute Leukemia and Solid Tumors }\end{array}$ & $\begin{array}{l}\text { Ex vivo expansion and infusion } \\
\text { without genetic modification }\end{array}$ & NCT00582816 \\
\hline \multicolumn{3}{|l|}{ Genetically modified $T$ cells } \\
\hline $\begin{array}{l}\text { 3rd generation gd2 specific chimeric antigen receptor } \\
\text { transduced autologous natural killer t-cells } \\
\text { for neuroblastoma (ginakit) }\end{array}$ & $\begin{array}{l}\text { Novel approach to use CAR within } \\
\text { cells with existing innate killing } \\
\text { properties }\end{array}$ & NCT02439788 \\
\hline $\begin{array}{l}\text { 3rd Generation GD-2 Chimeric Antigen Receptor and } \\
\text { icaspase Suicide Safety Switch, Neuroblastoma, } \\
\text { GRAIN (GRAIN) }\end{array}$ & $\begin{array}{l}\text { Third generation CAR for } \\
\text { neroblastoma }\end{array}$ & NCT01822652 \\
\hline $\begin{array}{l}\text { A Cancer Research UK Trial of Anti-GD2 T-cells (1RG- } \\
\text { CART) }\end{array}$ & $\begin{array}{l}\text { Second generation CAR for } \\
\text { neuroblastoma }\end{array}$ & NCT02761915 \\
\hline $\begin{array}{l}\text { A Phase I Trial of T Cells Expressing an Anti- } \\
\text { GD2 Chimeric Antigen Receptor in Children and Young } \\
\text { Adults With GD2+ Solid Tumors }\end{array}$ & $\begin{array}{l}\text { Third generation CAR for all } \\
\text { childhood cancers expressing GD2 } \\
\text { neroblastoma }\end{array}$ & NCT02107963 \\
\hline
\end{tabular}


Table 2. Potential combination agents to use with gene modified T cells for childhood solid cancers.

\begin{tabular}{|c|c|c|c|}
\hline Agent & Mechanisms of Action & Refs & Suitability for combination with 1RG-CART \\
\hline Sunitinib & $\begin{array}{l}\text { Reduces viability of MDSC in preclinical } \\
\text { studies and clinical trials probably through } \\
\text { targeting STAT3 }\end{array}$ & $54,56,57,110]$ & $\begin{array}{ll}\text { Readily available and well tolerated in paediatrics } \\
\text { Clinical trial evidence of inhibition of MDSC[43] }\end{array}$ \\
\hline $\begin{array}{l}\text { Chemotherapy } \\
\text { Gemcitabine }\end{array}$ & $\begin{array}{l}\text { Cytotoxic/biologic agents with high degree } \\
\text { of myeloid toxicity; Known to kill MSDC; } \\
\text { alternative agents of conditioning agent } \\
\text { pre adoptive transfer }\end{array}$ & {$[94,95,110]$} & $\begin{array}{l}\text { Readily available } \\
\text { Pediatric safety data available } \\
\text { Dose for MDSC depletion not known. } \\
\text { Potential to replace cyclophosphamide }\end{array}$ \\
\hline Plerixafor & $\begin{array}{l}\text { Disruption of CXCR4-CXCL12 interaction } \\
\text { at the surface of tumor cells }\end{array}$ & $11,65,103,105]$ & $\begin{array}{l}\text { CXCL12 known to be expressed on neuroblastoma stromal } \\
\text { cells } \\
\text { CXCR4 expression on MDSC drives their migration to } \\
\text { tumor }\end{array}$ \\
\hline Celecoxib & $\begin{array}{l}\text { COX2 inhibitor. COX2 stimulates Arginase } \\
\text { production in MDSC through stimulation by } \\
\text { PG-E2 }\end{array}$ & {$[40,61-67]$} & $\begin{array}{l}\text { COX } 2 \text { redegulated in neuroblastoma } \\
\text { Preclinical data for COX2 inhibitors in neuroblastoma } \\
\text { Celecoxib will tolerated and readily available } \\
\text { Clinical trial evidence of inhibition of MDSC function }\end{array}$ \\
\hline $\begin{array}{l}\text { Arginase Inhibitor } \\
\text { CB1158 }\end{array}$ & $\begin{array}{l}\text { Reverses the effect of tumor-induced } \\
\text { arginases that create an arginine-deplete } \\
\text { local and systemic microenvironment }\end{array}$ & {$[50,111]$} & $\begin{array}{l}\text { Drug currently in phase II in adults } \\
\text { Negotiation with pharma required }\end{array}$ \\
\hline Sildenafil & $\begin{array}{l}\text { targets PDE-5 in MDSC and has been } \\
\text { shown to augment antitumor immunity }\end{array}$ & [68-70]. & $\begin{array}{l}\text { Readily available } \\
\text { Good safety profile in paediatrics } \\
\text { No clinical trial data of its MDSC inhibitory effect }\end{array}$ \\
\hline $\begin{array}{l}\text { Ipilimumab +/- } \\
\text { Nivolumab }\end{array}$ & $\begin{array}{l}\text { Checkpoint inhibitor antibodies that target } \\
\text { the CTLA-4 and PL1 T cell inhibitory } \\
\text { pathways respectively. Nivolumab will } \\
\text { block interaction of PD-L1 high MDSC and } \\
\text { TAMs with CAR T cells. Ipilimumab blocks } \\
\text { inhibition induced by CD } 80 / 86 \text { on tumor } \\
\text { infiltrating myeloid cells and is cytotoxic for } \\
\text { regulatory T cells that are induced by } \\
\text { MDSC. Responses to ipilimumab correlate } \\
\text { with decrease in circulating MDSC }\end{array}$ & $\begin{array}{c}{[101,102,112} \\
113]\end{array}$ & $\begin{array}{l}\text { Anecodal use of PD1 blockade with third generation GD2 } \\
\text { CAR does not improve CAR expansion } \\
\text { Single agent Ipilimumab and PD1 pathway inhibitor studies } \\
\text { in paediatrics have limited clinical response } \\
\text { More activity for combination therapies than single agent in } \\
\text { many cancer types } \\
\text { Ipi/Nivo combination possible through BMS-otherwise } \\
\text { prohibitively expensive. }\end{array}$ \\
\hline $\begin{array}{l}\text { immunocytokines } \\
\text { L19-IL-2 } \\
\text { Hu14.18-IL2 }\end{array}$ & $\begin{array}{l}\text { Capable of local delivery of IL-2 to the } \\
\text { tumor site }\end{array}$ & {$[108,109]$} & $\begin{array}{l}\text { Pediatric phase I data for hu14.18-IL-2 but not for L19-IL-2 } \\
\text { Neither agent available commercially }\end{array}$ \\
\hline $\begin{array}{l}\text { All Trans Retinoic } \\
\text { Acid }\end{array}$ & $\begin{array}{l}\text { Reduces number of monocytic MDSCs and } \\
\text { diminishes the suppressive potency of } \\
\text { granulocytic MDSCs }\end{array}$ & {$[78-84,114]$. } & $\begin{array}{l}\text { Readily available and well tolerated in paediatrics } \\
\text { Animal data for MDSC inhibition } \\
\text { But no human proof of concept data }\end{array}$ \\
\hline Curcumin & $\begin{array}{l}\text { Anti inflammatory, anti Jak2/STAT3, COX2 } \\
\text { inhibition }\end{array}$ & {$[71-76]$} & $\begin{array}{l}\text { Strong preclinical evidence } \\
\text { Minimal clinical proof of concept studies } \\
\text { Minimal toxicity } \\
\text { Scheduling and pharmacodynamics unknown. }\end{array}$ \\
\hline Bevacizumab & $\begin{array}{l}\text { Normalizes the vasculature to decrease } \\
\text { tumor hypoxia, decrease pathway to } \\
\text { promote MDSC, and allow greater entry of } \\
\text { T cells into tumor }\end{array}$ & [115] & $\begin{array}{l}\text { Readily available but expensive } \\
\text { Good phase I data in paediatrics } \\
\text { The vascular normalization hypothesis for improved T cell } \\
\text { function in humans has yet to be tested }\end{array}$ \\
\hline Withaverin & $\begin{array}{l}\text { Anti-tumor activitiy in many models } \\
\text { Thought to function via STAT3 and } \\
\text { inhibition of immune suppression in } \\
\text { microenvironment }\end{array}$ & {$[85,86]$} & $\begin{array}{l}\text { Well tolerated but needs clinical evidence of } \\
\text { immunomodulatory activity in humans }\end{array}$ \\
\hline Nitroaspirin & $\begin{array}{l}\text { Increased the number and function of } \\
\text { tumor Ag-specific T lymphocytes in vitro } \\
\text { and in vivo by decreasing ARG and NOS } \\
\text { activity in CD11 }{ }^{+} \text {B lymphocytes }\end{array}$ & {$[58,110]$} & $\begin{array}{l}\text { No previous clinical trial evaluation in adult of pediatric } \\
\text { cancer patients }\end{array}$ \\
\hline Gemtuzumab & $\begin{array}{l}\text { Direct cytotoxicity of myeloid cells expressin } \\
\text { CD33 }\end{array}$ & [88] & $\begin{array}{l}\text { Safety and efficacy concerns in AML } \\
\text { No evidence that it is toxic/lytic to MDSC }\end{array}$ \\
\hline CSF-1 inhibitor & $\begin{array}{l}\text { Small molecules and antibodies to target } \\
\text { tumor associated macrophages } \\
\text { CSF-1R is expressed on MDSC }\end{array}$ & [87] & $\begin{array}{l}\text { Not evaluated in paediatrics } \\
\text { No preclinical data in neuroblastoma } \\
\text { Requires pharmaceutical collaboration }\end{array}$ \\
\hline Hyperbaric oxygen & Tissue hypoxia drives MDSC & [116] & $\begin{array}{l}\text { No clinical trial evidence for its effect on T cell function } \\
\text { Requires oxygen chamber which is unacceptable in phase } \\
\text { I pediatric setting } \\
\text { Evidence that HBO can drive tumor growth in some cancers }\end{array}$ \\
\hline IDO inhibitor & $\begin{array}{l}\text { IDO is produced by MDSC and by tumor } \\
\text { cells and inhibits T cells function by several } \\
\text { mechanisms including depletion of } \\
\text { tryptophan in microenvironment. }\end{array}$ & [77] & $\begin{array}{l}\text { No published evidence for an IDO mechanism in } \\
\text { neuroblastoma } \\
\text { 5-Methyl Tryptophan is the only agent tested in paediatrics } \\
\text { but has limited clinical efficacy }\end{array}$ \\
\hline MEK inhibitor & $\begin{array}{l}\text { Trametinib Improves functionality of } \\
\text { adoptively transferred T cells in Pmel } \\
\text { model. MEK pathway activation in } \\
\text { neuroblastoma }\end{array}$ & [117] & $\begin{array}{l}\text { Phase I data available in paediatrics and well tolerated } \\
\text { No clinical evidence of its effect on MDSC function or } \\
\text { activity in neuroblastoma } \\
\text { Requires pharmaceutical collaboration }\end{array}$ \\
\hline 5-FU & Myelotoxic chemotherapy & {$[96,97]$} & $\begin{array}{l}\text { No clinical evidence of its inhibitory function on MDSC } \\
\text { Contradictory data; potential for stimulation of MDSC }\end{array}$ \\
\hline $\begin{array}{l}\text { TGF-beta inhibition } \\
\text { Fresolimab } \\
\text { Galunisertib }\end{array}$ & $\begin{array}{l}\text { TGF- } \beta \text { is a fundamental pathway of } \\
\text { suppression by MDSC. }\end{array}$ & & $\begin{array}{l}\text { Development and proof of efficacy of TGF- } \beta \text { inhibitors has } \\
\text { been disappointing despite many years of effort }\end{array}$ \\
\hline $\begin{array}{l}\text { Lenolidamide and } \\
\text { related inhibitors }\end{array}$ & $\begin{array}{l}\text { Inhibitory effects on range of regulatory } \\
\text { immune cells }\end{array}$ & & $\begin{array}{l}\text { Competing with other studies in pediatrics } \\
\text { Little direct evidence for role in neuroblastoma } \\
\text { Requires pharmaceutical collaboration }\end{array}$ \\
\hline
\end{tabular}


Table 3. Examples of potential target antigens for pediatric cancers. Direct targeting with antibodies or CAR T cells is possible with molecules naturally resident on the cell surface and absent from most normal tissues. Tumor specific antigens arise as a result of a characteristic mutation. For such an antigen to be targeted by $T$ cells the mutated amino acids must have the appropriate affinity for self $\mathrm{MHC}$ to be presented as a peptide fragment; for example the peptides spanning a chromosomal translocation breakpoint. Non membrane bound tumor associated antigens also require presentation on the cell membrane with $\mathrm{MHC}$ and are non mutated (self) peptides but distinguishable by the immune system from non-tumor tissues by virtue of low level expression on normal tissues. For detailed reference list see [118, 119].

\begin{tabular}{|c|c|}
\hline Antigen & Cancer \\
\hline \multicolumn{2}{|c|}{ Directly Targetable cell surface molecules } \\
\hline GD2 & Neuroblastoma, sarcomas \\
\hline ALK & Neuroblastoma, IMT, rhabdomyosarcoma \\
\hline FGFR4 & Rhabdomyosarcoma \\
\hline B7H3 & Pontine glioma, neuroblastoma \\
\hline IGF1R & Ewing sarcoma, RMS \\
\hline EGFR & Medulloblastoma, glioma, sarcoma \\
\hline STEAP-1 & Ewing sarcoma \\
\hline $\begin{array}{l}\text { Fetal Acetylcholine } \\
\text { receptor }\end{array}$ & Ewing sarcoma, rhabdomyosarcoma \\
\hline PDGFR & High grade glioma \\
\hline \multicolumn{2}{|c|}{ Tumor-Specific Antigens } \\
\hline PAX3/7-FOXO & Alveolar rhabdomyosarcoma \\
\hline Histone H3 mutation & Midline high grade gliomas \\
\hline Ewings translocations & Ewing family sarcomas \\
\hline EWS-WT1 fusion & Desmoplastic small round cell tumor \\
\hline \multicolumn{2}{|c|}{ Non-membrane bound Tumor associated antigens } \\
\hline WT1 & Wilms' rhabdomyosarcoma \\
\hline NY-ESO & Synovial sarcoma \\
\hline PRAME & $\begin{array}{l}\text { Neuroblastoma, pontine glioma, Ewing, } \\
\text { osteosarcoma, medulloblastoma }\end{array}$ \\
\hline
\end{tabular}




\section{References}

1. Schumacher TN, Schreiber RD. Neoantigens in cancer immunotherapy. Science, 2015 348: 69-74.

2. Hanahan D, Weinberg RA. Hallmarks of cancer: the next generation. Cell, 2011 144: 646-674.

3. Haworth KB, Leddon JL, Chen C-Y, Horwitz EM, Mackall CL, Cripe TP. Going back to class I: MHC and immunotherapies for childhood cancer. Pediatr Blood Cancer, 2015 62: 571-576.

4. Yu H, Kortylewski M, Pardoll D. Crosstalk between cancer and immune cells: role of STAT3 in the tumour microenvironment. Nat Rev Immunol, 2007 7: 41-51.

5. Mackall CL, Merchant MS, Fry TJ. Immune-based therapies for childhood cancer. Nat Rev Clin Oncol, 2014 11: 693-703.

6. Asgharzadeh S, Salo JA, Ji L, Oberthuer A, Fischer M, Berthold F, Hadjidaniel M, Liu CW-Y, Metelitsa LS, Pique-Regi R, Wakamatsu P, Villablanca JG, Kreissman SG, Matthay KK, Shimada H, London WB, Sposto R, Seeger RC. Clinical significance of tumor-associated inflammatory cells in metastatic neuroblastoma. $J$ Clin Oncol, 2012 30: 3525-3532.

7. Nabarro S, Himoudi N, Papanastasiou A, Gilmour K, Gibson S, Sebire N, Thrasher A, Blundell MP, Hubank M, Canderan G, Anderson J. Coordinated oncogenic transformation and inhibition of host immune responses by the PAX3-FKHR fusion oncoprotein. J Exp Med, 2005 202: 1399-1410.

8. Siepl C, Bodmer S, Frei K, MacDonald HR, De Martin R, Hofer E, Fontana A. The glioblastoma-derived T cell suppressor factor/transforming growth factor-beta 2 inhibits T cell growth without affecting the interaction of interleukin 2 with its receptor. Eur J Immunol, 1988 18: 593-600.

9. Kuppner MC, Hamou MF, Sawamura Y, Bodmer S, de Tribolet N. Inhibition of lymphocyte function by glioblastoma-derived transforming growth factor beta 2 . J Neurosurg, 1989 71: 211-217.

10. Wondimu A, Liu Y, Su Y, Bobb D, Ma JSY, Chakrabarti L, Radoja S, Ladisch S. Gangliosides drive the tumor infiltration and function of myeloid-derived suppressor cells. Cancer Res, 2014 74: 5449-5457.

11. Joyce JA, Fearon DT. T cell exclusion, immune privilege, and the tumor microenvironment. Science, 2015 348: 74-80.

12. Van Allen EM, Miao D, Schilling B, Shukla SA, Blank C, Zimmer L, Sucker A, Hillen U, Geukes Foppen MH, Goldinger SM, Utikal J, Hassel JC, Weide B, Kaehler KC, Loquai C, Mohr P, Gutzmer R, Dummer R, Gabriel S, Wu CJ, Schadendorf D, Garraway LA. Genomic correlates of response to CTLA-4 blockade in metastatic melanoma. Science, 2015 350: 207-211.

13. Taube JM, Anders RA, Young GD, Xu H, Sharma R, McMiller TL, Chen S, Klein AP, Pardoll DM, Topalian SL, Chen L. Colocalization of inflammatory response with B7-h1 expression in human melanocytic lesions supports an adaptive resistance 
mechanism of immune escape. Sci Transl Med, 2012 4: 127ra37-127ra37.

14. Gubin MM, Schreiber RD. CANCER. The odds of immunotherapy success. Science, 2015 350: 158-159.

15. Alexandrov LB, Nik-Zainal S, Wedge DC, Aparicio SAJR, Behjati S, Biankin AV, Bignell GR, Bolli N, Borg A, Børresen-Dale A-L, Boyault S, Burkhardt B, Butler AP, Caldas C, Davies HR, Desmedt C, Eils R, Eyfjörd JE, Foekens JA, Greaves M, Hosoda F, Hutter B, Ilicic T, Imbeaud S, Imielinski M, Imielinsk M, Jäger N, Jones DTW, Jones D, Knappskog S, Kool M, Lakhani SR, López-Otín C, Martin S, Munshi NC, Nakamura H, Northcott PA, Pajic M, Papaemmanuil E, Paradiso A, Pearson JV, Puente XS, Raine K, Ramakrishna M, Richardson AL, Richter J, Rosenstiel P, Schlesner M, Schumacher TN, Span PN, Teague JW, Totoki Y, Tutt ANJ, ValdésMas R, van Buuren MM, van 't Veer L, Vincent-Salomon A, Waddell N, Yates LR, Initiative APCG, Consortium IBC, Consortium IM-S, PedBrain I, Zucman-Rossi J, Futreal PA, McDermott U, Lichter P, Meyerson M, Grimmond SM, Siebert R, Campo E, Shibata T, Pfister SM, Campbell PJ, Stratton MR. Signatures of mutational processes in human cancer. Nature, 2013 500: 415-421.

16. Merchant MS, Wright M, Baird K, Wexler LH, Rodríguez-Galindo C, Bernstein D, Delbrook C, Lodish M, Bishop R, Wolchok JD, Streicher H, Mackall CL. Phase I Clinical Trial of Ipilimumab in Pediatric Patients with Advanced Solid Tumors. Clin Cancer Res, 2016 22: 1364-1370.

17. Ansell SM, Lesokhin AM, Borrello I, Halwani A, Scott EC, Gutierrez M, Schuster SJ, Millenson MM, Cattry D, Freeman GJ, Rodig SJ, Chapuy B, Ligon AH, Zhu L, Grosso JF, Kim SY, Timmerman JM, Shipp MA, Armand P. PD-1 blockade with nivolumab in relapsed or refractory Hodgkin's lymphoma. N Engl J Med, 2015372 : 311-319.

18. Bouffet E, Larouche V, Campbell BB, Merico D, de Borja R, Aronson M, Durno C, Krueger J, Cabric V, Ramaswamy V, Zhukova N, Mason G, Farah R, Afzal S, Yalon M, Rechavi G, Magimairajan V, Walsh MF, Constantini S, Dvir R, Elhasid R, Reddy A, Osborn M, Sullivan M, Hansford J, Dodgshun A, Klauber-Demore N, Peterson L, Patel S, Lindhorst S, Atkinson J, Cohen Z, Laframboise R, Dirks P, Taylor M, Malkin D, Albrecht S, Dudley RWR, Jabado N, Hawkins CE, Shlien A, Tabori U. Immune Checkpoint Inhibition for Hypermutant Glioblastoma Multiforme Resulting From Germline Biallelic Mismatch Repair Deficiency. J Clin Oncol, 2016 34: 2206-2211.

19. Schumacher TN, Schreiber RD. Neoantigens in cancer immunotherapy. Science, 2015 348: 69-74.

20. Linnemann C, van Buuren MM, Bies L, Verdegaal EME, Schotte R, Calis JJA, Behjati S, Velds A, Hilkmann H, Atmioui DE, Visser M, Stratton MR, Haanen JBAG, Spits $\mathrm{H}$, van der Burg SH, Schumacher TNM. High-throughput epitope discovery reveals frequent recognition of neo-antigens by CD4+ T cells in human melanoma. Nat Med, 2015 21: 81-85.

21. Rosenberg SA, Restifo NP. Adoptive cell transfer as personalized immunotherapy for human cancer. Science, 2015 348: 62-68.

22. Paulos CM, Wrzesinski C, Kaiser A, Hinrichs CS, Chieppa M, Cassard L, Palmer DC, Boni A, Muranski P, Yu Z, Gattinoni L, Antony PA, Rosenberg SA, Restifo NP. Microbial translocation augments the function of adoptively transferred self/tumorspecific CD8+ T cells via TLR4 signaling. J Clin Invest, 2007 117: 2197-2204. 
23. Specific activation and targeting of cytotoxic lymphocytes through chimeric single chains consisting of antibody-binding domains and the gamma or zeta subunits of the immunoglobulin and T-cell receptors. [Internet], 1993 90: 720-724. Available from: http://linkinghub.elsevier.com/retrieve/pii/S0092867415006376

24. Jensen MC, Riddell SR. Design and implementation of adoptive therapy with chimeric antigen receptor-modified T cells. Immunol Rev, 2014 257: 127-144.

25. Amrolia PJ, Pule M. Chimeric antigen receptor T cells for ALL. Lancet, 2015 385: 488-490.

26. Lee DW, Kochenderfer JN, Stetler-Stevenson M, Cui YK, Delbrook C, Feldman SA, Fry TJ, Orentas R, Sabatino M, Shah NN, Steinberg SM, Stroncek D, Tschernia N, Yuan C, Zhang H, Zhang L, Rosenberg SA, Wayne AS, Mackall CL. T cells expressing CD19 chimeric antigen receptors for acute lymphoblastic leukaemia in children and young adults: a phase 1 dose-escalation trial. Lancet, 2015 385: 517528.

27. Porter DL, Levine BL, Kalos M, Bagg A, June CH. Chimeric Antigen ReceptorModified T Cells in Chronic Lymphoid Leukemia. N Engl J Med, 2011.

28. Turtle CJ, Hanafi L-A, Berger C, Gooley TA, Cherian S, Hudecek M, Sommermeyer D, Melville K, Pender B, Budiarto TM, Robinson E, Steevens NN, Chaney C, Soma L, Chen X, Yeung C, Wood B, Li D, Cao J, Heimfeld S, Jensen MC, Riddell SR, Maloney DG. CD19 CAR-T cells of defined CD4+:CD8+ composition in adult B cell ALL patients. J Clin Invest, 2016 126: 2123-2138.

29. Beatty GL, O'Hara M. Chimeric antigen receptor-modified T cells for the treatment of solid tumors: Defining the challenges and next steps. Pharmacol Ther, 2016.

30. ORourke DM, Nasrallah M, Morrissette JJ, Melenhorst JJ, Lacey SF, Mansfield K, Martinez-Lage M, Desai AS, Brem S, Maloney E, Mohan S, Wang S, Verma G, Navenot J-M, Shen A, Zheng Z, Levine B, Okada H, June CH, Maus MV. Pilot study of $T$ cells redirected to EGFRvIll with a chimeric antigen receptor in patients with EGFRvIll+ glioblastoma., in

31. Morello A, Sadelain M, Adusumilli PS. Mesothelin-Targeted CARs: Driving T Cells to Solid Tumors. Cancer Discov, 2016 6: 133-146.

32. Bronte V, Brandau S, Chen S-H, Colombo MP, Frey AB, Greten TF, Mandruzzato S, Murray PJ, Ochoa A, Ostrand-Rosenberg S, Rodriguez PC, Sica A, Umansky V, Vonderheide RH, Gabrilovich DI. Recommendations for myeloid-derived suppressor cell nomenclature and characterization standards. Nat Commun, 2016 7: 12150.

33. Marvel D, Gabrilovich DI. Myeloid-derived suppressor cells in the tumor microenvironment: expect the unexpected. J Clin Invest, 2015 125: 3356-3364.

34. Srivastava MK, Sinha P, Clements VK, Rodriguez P, Ostrand-Rosenberg S. Myeloid-derived suppressor cells inhibit T-cell activation by depleting cystine and cysteine. Cancer Res, 2010 70: 68-77.

35. Rodriguez PC, Quiceno DG, Ochoa AC. L-arginine availability regulates Tlymphocyte cell-cycle progression. Blood, 2007 109: 1568-1573. 
36. Li H, Han Y, Guo Q, Zhang M, Cao X. Cancer-expanded myeloid-derived suppressor cells induce anergy of NK cells through membrane-bound TGF-beta 1. J Immunol, 2009 182: 240-249.

37. Elkabets M, Ribeiro VSG, Dinarello CA, Ostrand-Rosenberg S, Di Santo JP, Apte $\mathrm{RN}$, Vosshenrich CAJ. IL-1 $\beta$ regulates a novel myeloid-derived suppressor cell subset that impairs NK cell development and function. Eur J Immunol, 2010 40: 3347-3357.

38. Huang B, Pan P-Y, Li Q, Sato Al, Levy DE, Bromberg J, Divino CM, Chen S-H. Gr-1+CD115+ immature myeloid suppressor cells mediate the development of tumor-induced $T$ regulatory cells and T-cell anergy in tumor-bearing host. Cancer Res, 2006 66: 1123-1131.

39. Mao Y, Poschke I, Wennerberg E, Pico de Coaña Y, Egyhazi Brage S, Schultz I, Hansson J, Masucci G, Lundqvist A, Kiessling R. Melanoma-educated CD14+ cells acquire a myeloid-derived suppressor cell phenotype through COX-2-dependent mechanisms. Cancer Res, 2013 73: 3877-3887.

40. Fujita M, Kohanbash G, Fellows-Mayle W, Hamilton RL, Komohara Y, Decker SA, Ohlfest JR, Okada H. COX-2 blockade suppresses gliomagenesis by inhibiting myeloid-derived suppressor cells. Cancer Res, 2011 71: 2664-2674.

41. Gabitass RF, Annels NE, Stocken DD, Pandha HA, Middleton GW. Elevated myeloid-derived suppressor cells in pancreatic, esophageal and gastric cancer are an independent prognostic factor and are associated with significant elevation of the Th2 cytokine interleukin-13. Cancer Immunol Immunother, 2011 60: 1419-1430.

42. Draghiciu O, Lubbers J, Nijman HW, Daemen T. Myeloid derived suppressor cells-An overview of combat strategies to increase immunotherapy efficacy. Oncoimmunology, 2015 4: e954829.

43. Diaz-Montero CM, Salem ML, Nishimura MI, Garrett-Mayer E, Cole DJ, Montero AJ. Increased circulating myeloid-derived suppressor cells correlate with clinical cancer stage, metastatic tumor burden, and doxorubicin-cyclophosphamide chemotherapy. Cancer Immunol Immunother, 2009 58: 49-59.

44. Metelitsa LS, Wu H-W, Wang H, Yang Y, Warsi Z, Asgharzadeh S, Groshen S, Wilson SB, Seeger RC. Natural killer T cells infiltrate neuroblastomas expressing the chemokine CCL2. J Exp Med, 2004 199: 1213-1221.

45. Ara T, Song L, Shimada H, Keshelava N, Russell HV, Metelitsa LS, Groshen SG, Seeger RC, DeClerck YA. Interleukin-6 in the bone marrow microenvironment promotes the growth and survival of neuroblastoma cells. Cancer Res, 2009 69: 329-337.

46. Liu D, Song L, Wei J, Courtney AN, Gao X, Marinova E, Guo L, Heczey A, Asgharzadeh S, Kim E, Dotti G, Metelitsa LS. IL-15 protects NKT cells from inhibition by tumor-associated macrophages and enhances antimetastatic activity. J Clin Invest, 2012 122: 2221-2233.

47. Santilli G, Piotrowska I, Cantilena S, Chayka O, D'Alicarnasso M, Morgenstern DA, Himoudi N, Pearson K, Anderson J, Thrasher AJ, Sala A. Polyphenon [corrected] $E$ enhances the antitumor immune response in neuroblastoma by inactivating myeloid suppressor cells. Clin Cancer Res, 2013 19: 1116-1125. 
48. Santilli G, Anderson J, Thrasher AJ, Sala A. Catechins and antitumor immunity: Not MDSC's cup of tea. Oncoimmunology, 2013 2: e24443.

49. Apps JR, Hasan F, Campus O, Behjati S, Jacques TS, J Sebire N, Anderson J. The immune environment of paediatric solid malignancies: evidence from an immunohistochemical study of clinical cases. Fetal Pediatr Pathol, 2013 32: 298307.

50. Mussai F, Egan S, Hunter S, Webber H, Fisher J, Wheat R, McConville C, Sbirkov Y, Wheeler K, Bendle G, Petrie K, Anderson J, Chesler L, De Santo C. Neuroblastoma Arginase Activity Creates an Immunosuppressive Microenvironment That Impairs Autologous and Engineered Immunity. Cancer Res, 2015 75: 30433053.

51. Raffaghello L, Prigione I, Airoldi I, Camoriano M, Levreri I, Gambini C, Pende D, Steinle A, Ferrone S, Pistoia V. Downregulation and/or release of NKG2D ligands as immune evasion strategy of human neuroblastoma. Neoplasia, 2004 6: 558-568.

52. Kloess S, Huenecke S, Piechulek D, Esser R, Koch J, Brehm C, Soerensen J, Gardlowski T, Brinkmann A, Bader P, Passweg J, Klingebiel T, Schwabe D, Koehl U. IL-2-activated haploidentical NK cells restore NKG2D-mediated NK-cell cytotoxicity in neuroblastoma patients by scavenging of plasma MICA. Eur J Immunol, 2010 40: 3255-3267.

53. Stroncek DF, Ren J, Lee DW, Tran M, Frodigh SE, Sabatino M, Khuu H, Merchant MS, Mackall CL. Myeloid cells in peripheral blood mononuclear cell concentrates inhibit the expansion of chimeric antigen receptor T cells. Cytotherapy, 2016 18: 893-901.

54. van Hooren L, Georganaki M, Huang H, Mangsbo SM, Dimberg A. Sunitinib enhances the antitumor responses of agonistic CD40-antibody by reducing MDSCs and synergistically improving endothelial activation and T-cell recruitment. Oncotarget, 2016 7: 50277-50289.

55. Chen H-M, Ma G, Gildener-Leapman N, Eisenstein S, Coakley BA, Ozao J, Mandeli J, Divino C, Schwartz M, Sung M, Ferris R, Kao J, Wang L-H, Pan P-Y, Ko EC, Chen S-H. Myeloid-Derived Suppressor Cells as an Immune Parameter in Patients with Concurrent Sunitinib and Stereotactic Body Radiotherapy. Clin Cancer Res, 2015 21: 4073-4085.

56. Guislain A, Gadiot J, Kaiser A, Jordanova ES, Broeks A, Sanders J, van Boven H, de Gruijl TD, Haanen JBAG, Bex A, Blank CU. Sunitinib pretreatment improves tumor-infiltrating lymphocyte expansion by reduction in intratumoral content of myeloid-derived suppressor cells in human renal cell carcinoma. Cancer Immunol Immunother, 2015 64: 1241-1250.

57. Ko JS, Zea AH, Rini BI, Ireland JL, Elson P, Cohen P, Golshayan A, Rayman PA, Wood L, Garcia J, Dreicer R, Bukowski R, Finke JH. Sunitinib mediates reversal of myeloid-derived suppressor cell accumulation in renal cell carcinoma patients. Clin Cancer Res, 2009 15: 2148-2157.

58. De Santo C, Serafini P, Marigo I, Dolcetti L, Bolla M, Del Soldato P, Melani C, Guiducci C, Colombo MP, lezzi M, Musiani P, Zanovello P, Bronte V. Nitroaspirin corrects immune dysfunction in tumor-bearing hosts and promotes tumor eradication by cancer vaccination. Proc Natl Acad Sci USA, 2005 102: 4185-4190. 
59. Johnsen JI, Lindskog M, Ponthan F, Pettersen I, Elfman L, Orrego A, Sveinbjörnsson B, Kogner P. Cyclooxygenase-2 is expressed in neuroblastoma, and nonsteroidal anti-inflammatory drugs induce apoptosis and inhibit tumor growth in vivo. Cancer Res, 2004 64: 7210-7215.

60. Rasmuson A, Kock A, Fuskevåg OM, Kruspig B, Simón-Santamaría J, Gogvadze $\mathrm{V}$, Johnsen JI, Kogner P, Sveinbjörnsson B. Autocrine prostaglandin E2 signaling promotes tumor cell survival and proliferation in childhood neuroblastoma. PLoS ONE, 2012 7: e29331.

61. Zea AH, Rodriguez PC, Atkins MB, Hernandez C, Signoretti S, Zabaleta J, McDermott D, Quiceno D, Youmans A, O'Neill A, Mier J, Ochoa AC. Arginaseproducing myeloid suppressor cells in renal cell carcinoma patients: a mechanism of tumor evasion. Cancer Res, 2005 65: 3044-3048.

62. Veltman JD, Lambers MEH, van Nimwegen M, Hendriks RW, Hoogsteden HC, Aerts JGJV, Hegmans JPJJ. COX-2 inhibition improves immunotherapy and is associated with decreased numbers of myeloid-derived suppressor cells in mesothelioma. Celecoxib influences MDSC function. BMC Cancer, 2010 10: 464.

63. Talmadge JE, Hood KC, Zobel LC, Shafer LR, Coles M, Toth B.

Chemoprevention by cyclooxygenase-2 inhibition reduces immature myeloid suppressor cell expansion. Int Immunopharmacol, 2007 7: 140-151.

64. Obermajer N, Muthuswamy R, Lesnock J, Edwards RP, Kalinski P. Positive feedback between PGE2 and COX2 redirects the differentiation of human dendritic cells toward stable myeloid-derived suppressor cells. Blood, 2011 118: 5498-5505.

65. Obermajer N, Muthuswamy R, Odunsi K, Edwards RP, Kalinski P. PGE(2)induced CXCL12 production and CXCR4 expression controls the accumulation of human MDSCs in ovarian cancer environment. Cancer Res, 2011 71: 7463-7470.

66. Muthuswamy R, Corman JM, Dahl K, Chatta GS, Kalinski P. Functional reprogramming of human prostate cancer to promote local attraction of effector CD8(+) T cells. Prostate, 2016 76: 1095-1105.

67. Zhao Q, Guo J, Wang G, Chu Y, Hu X. Suppression of immune regulatory cells with combined therapy of celecoxib and sunitinib in renal cell carcinoma. Oncotarget, 20165.

68. Karakhanova S, Link J, Heinrich M, Shevchenko I, Yang Y, Hassenpflug M, Bunge H, Ahn von K, Brecht R, Mathes A, Maier C, Umansky V, Werner J, Bazhin AV. Characterization of myeloid leukocytes and soluble mediators in pancreatic cancer: importance of myeloid-derived suppressor cells. Oncoimmunology, 2015 4: e998519.

69. Serafini P, Meckel K, Kelso M, Noonan K, Califano J, Koch W, Dolcetti L, Bronte V, Borrello I. Phosphodiesterase-5 inhibition augments endogenous antitumor immunity by reducing myeloid-derived suppressor cell function. J Exp Med, 2006 203: 2691-2702.

70. Califano JA, Khan Z, Noonan KA, Rudraraju L, Zhang Z, Wang H, Goodman S, Gourin CG, Ha PK, Fakhry C, Saunders J, Levine M, Tang M, Neuner G, Richmon JD, Blanco R, Agrawal N, Koch WM, Marur S, Weed DT, Serafini P, Borrello I. Tadalafil augments tumor specific immunity in patients with head and neck 
squamous cell carcinoma. Clin Cancer Res, 2015 21: 30-38.

71. Bill MA, Nicholas C, Mace TA, Etter JP, Li C, Schwartz EB, Fuchs JR, Young GS, Lin L, Lin J, He L, Phelps M, Li P-K, Lesinski GB. Structurally modified curcumin analogs inhibit STAT3 phosphorylation and promote apoptosis of human renal cell carcinoma and melanoma cell lines. PLoS ONE, 2012 7: e40724.

72. Bill MA, Fuchs JR, Li C, Yui J, Bakan C, Benson DM, Schwartz EB, Abdelhamid D, Lin J, Hoyt DG, Fossey SL, Young GS, Carson WE, Li P-K, Lesinski GB. The small molecule curcumin analog FLLL32 induces apoptosis in melanoma cells via STAT3 inhibition and retains the cellular response to cytokines with anti-tumor activity. Mol Cancer, 2010 9: 165.

73. Zhou J, Donatelli SS, Gilvary DL, Tejera MM, Eksioglu EA, Chen X, Coppola D, Wei S, Djeu JY. Therapeutic targeting of myeloid-derived suppressor cells involves a novel mechanism mediated by clusterin. Sci Rep, 2016 6: 29521.

74. Tu SP, Jin H, Shi JD, Zhu LM, Suo Y, Lu G, Liu A, Wang TC, Yang CS.

Curcumin induces the differentiation of myeloid-derived suppressor cells and inhibits their interaction with cancer cells and related tumor growth. Cancer Prev Res (Phila), 2012 5: 205-215.

75. Singh M, Ramos I, Asafu-Adjei D, Quispe-Tintaya W, Chandra D, Jahangir A, Zang X, Aggarwal BB, Gravekamp C. Curcumin improves the therapeutic efficacy of Listeria(at)-Mage-b vaccine in correlation with improved T-cell responses in blood of a triple-negative breast cancer model 4T1. Cancer Med, 2013 2: 571-582.

76. Wolff JE, Brown RE, Buryanek J, Pfister S, Vats TS, Rytting ME. Preliminary experience with personalized and targeted therapy for pediatric brain tumors. Pediatr Blood Cancer, 2012 59: 27-33.

77. Vacchelli E, Aranda F, Eggermont A, Sautès-Fridman C, Tartour E, Kennedy EP, Platten M, Zitvogel L, Kroemer G, Galluzzi L. Trial watch: IDO inhibitors in cancer therapy. Oncoimmunology, 2014 3: e957994.

78. Walkley CR, Yuan Y-D, Chandraratna RAS, McArthur GA. Retinoic acid receptor antagonism in vivo expands the numbers of precursor cells during granulopoiesis. Leukemia, 2002 16: 1763-1772.

79. Kuwata T, Wang IM, Tamura T, Ponnamperuma RM, Levine R, Holmes KL, Morse HC, De Luca LM, Ozato K. Vitamin A deficiency in mice causes a systemic expansion of myeloid cells. Blood, 2000 95: 3349-3356.

80. Kusmartsev S, Cheng F, Yu B, Nefedova Y, Sotomayor E, Lush R, Gabrilovich D. All-trans-retinoic acid eliminates immature myeloid cells from tumor-bearing mice and improves the effect of vaccination. Cancer Res, 2003 63: 4441-4449.

81. Waldron TJ, Quatromoni JG, Karakasheva TA, Singhal S, Rustgi AK. Myeloid derived suppressor cells: Targets for therapy. Oncoimmunology, 2013 2: e24117.

82. Nefedova Y, Fishman M, Sherman S, Wang X, Beg AA, Gabrilovich DI. Mechanism of all-trans retinoic acid effect on tumor-associated myeloid-derived suppressor cells. Cancer Res, 2007 67: 11021-11028.

83. Almand B, Clark JI, Nikitina E, van Beynen J, English NR, Knight SC, Carbone 
DP, Gabrilovich DI. Increased production of immature myeloid cells in cancer patients: a mechanism of immunosuppression in cancer. J Immunol, 2001 166: 678689.

84. Ma J, Liu Y, Li Y, Gu J, Liu J, Tang J, Wang J, Ryffel B, Shen Y, Brand D, Liu Z, Zheng SG. Differential role of all-trans retinoic acid in promoting the development of CD4+ and CD8+ regulatory T cells. J Leukoc Biol, 2014 95: 275-283.

85. Sinha $P$, Ostrand-Rosenberg $S$. Myeloid-derived suppressor cell function is reduced by Withaferin $\mathrm{A}$, a potent and abundant component of Withania somnifera root extract. Cancer Immunol Immunother, 2013 62: 1663-1673.

86. Muralikrishnan G, Dinda AK, Shakeel F. Immunomodulatory effects of Withania somnifera on azoxymethane induced experimental colon cancer in mice. Immunol Invest, 2010 39: 688-698.

87. Zhu Y, Knolhoff BL, Meyer MA, Nywening TM, West BL, Luo J, Wang-Gillam A, Goedegebuure SP, Linehan DC, DeNardo DG. CSF1/CSF1R blockade reprograms tumor-infiltrating macrophages and improves response to T-cell checkpoint immunotherapy in pancreatic cancer models. Cancer Res, 2014 74: 5057-5069.

88. Rashidi A, Walter RB. Antigen-specific immunotherapy for acute myeloid leukemia: where are we now, and where do we go from here? Expert Rev Hematol, 2016 9: 335-350.

89. Condamine T, Kumar V, Ramachandran IR, Youn J-I, Celis E, Finnberg N, ElDeiry WS, Winograd R, Vonderheide RH, English NR, Knight SC, Yagita H, McCaffrey JC, Antonia S, Hockstein N, Witt R, Masters G, Bauer T, Gabrilovich DI. ER stress regulates myeloid-derived suppressor cell fate through TRAIL-R-mediated apoptosis. J Clin Invest, 2014 124: 2626-2639.

90. Ding Z-C, Lu X, Yu M, Lemos H, Huang L, Chandler P, Liu K, Walters M, Krasinski A, Mack M, Blazar BR, Mellor AL, Munn DH, Zhou G. Immunosuppressive myeloid cells induced by chemotherapy attenuate antitumor CD4+ T-cell responses through the PD-1-PD-L1 axis. Cancer Res, 2014 74: 3441-3453.

91. Ding Z-C, Munn DH, Zhou G. Chemotherapy-induced myeloid suppressor cells and antitumor immunity: The Janus face of chemotherapy in immunomodulation. Oncoimmunology, 2014 3: e954471.

92. Angulo I, las Heras de FG, García-Bustos JF, Gargallo D, Muñoz-Fernández MA, Fresno M. Nitric oxide-producing CD11b(+)Ly-6G(Gr-1)(+)CD31(ER-MP12)(+) cells in the spleen of cyclophosphamide-treated mice: implications for T-cell responses in immunosuppressed mice. Blood, 2000 95: 212-220.

93. Mikyšková R, Indrová M, Polláková V, Bieblová J, Símová J, Reiniš M. Cyclophosphamide-induced myeloid-derived suppressor cell population is immunosuppressive but not identical to myeloid-derived suppressor cells induced by growing TC-1 tumors. J Immunother, 2012 35: 374-384.

94. Suzuki E, Kapoor V, Jassar AS, Kaiser LR, Albelda SM. Gemcitabine selectively eliminates splenic Gr-1+/CD11b+ myeloid suppressor cells in tumor-bearing animals and enhances antitumor immune activity. Clin Cancer Res, 2005 11: 6713-6721.

95. Le HK, Graham L, Cha E, Morales JK, Manjili MH, Bear HD. Gemcitabine directly 
inhibits myeloid derived suppressor cells in BALB/c mice bearing 4T1 mammary carcinoma and augments expansion of T cells from tumor-bearing mice. Int Immunopharmacol, 2009 9: 900-909.

96. Vincent J, Mignot G, Chalmin F, Ladoire S, Bruchard M, Chevriaux A, Martin F, Apetoh L, Rébé C, Ghiringhelli F. 5-Fluorouracil selectively kills tumor-associated myeloid-derived suppressor cells resulting in enhanced T cell-dependent antitumor immunity. Cancer Res, 2010 70: 3052-3061.

97. Bruchard $M$, Mignot $G$, Derangère $V$, Chalmin $F$, Chevriaux $A$, Végran $F$, Boireau W, Simon B, Ryffel B, Connat JL, Kanellopoulos J, Martin F, Rébé C, Apetoh L, Ghiringhelli $F$. Chemotherapy-triggered cathepsin B release in myeloid-derived suppressor cells activates the Nlrp3 inflammasome and promotes tumor growth. Nat Med, 2013 19: 57-64.

98. Anderlini P, Saliba RM, Ledesma C, Plair T, Alousi AM, Hosing CM, Khouri IF, Nieto Y, Popat UR, Shpall EJ, Fanale MA, Hagemeister FB, Oki Y, Neelapu S, Romaguera JE, Younes A, Champlin RE. Gemcitabine, Fludarabine, and Melphalan for Reduced-Intensity Conditioning and Allogeneic Stem Cell Transplantation for Relapsed and Refractory Hodgkin Lymphoma. Biol Blood Marrow Transplant, 2016 22: 1333-1337.

99. Pinton L, Solito S, Damuzzo V, Francescato S, Pozzuoli A, Berizzi A, Mocellin S, Rossi CR, Bronte V, Mandruzzato S. Activated T cells sustain myeloid-derived suppressor cell-mediated immune suppression. Oncotarget, 2016 7: 1168-1184.

100. Peggs KS, Quezada SA, Chambers CA, Korman AJ, Allison JP. Blockade of CTLA-4 on both effector and regulatory T cell compartments contributes to the antitumor activity of anti-CTLA-4 antibodies. J Exp Med, 2009 206: 1717-1725.

101. Meyer C, Cagnon L, Costa-Nunes CM, Baumgaertner P, Montandon N, Leyvraz L, Michielin O, Romano E, Speiser DE. Frequencies of circulating MDSC correlate with clinical outcome of melanoma patients treated with ipilimumab. Cancer Immunol Immunother, 2014 63: 247-257.

102. Tarhini AA, Edington $H$, Butterfield $L H$, Lin $Y$, Shuai $Y$, Tawbi $H$, Sander $C$, Yin Y, Holtzman M, Johnson J, Rao UNM, Kirkwood JM. Immune monitoring of the circulation and the tumor microenvironment in patients with regionally advanced melanoma receiving neoadjuvant ipilimumab. PLoS ONE, 2014 9: e87705.

103. Feig C, Jones JO, Kraman M, Wells RJB, Deonarine A, Chan DS, Connell CM, Roberts EW, Zhao Q, Caballero OL, Teichmann SA, Janowitz T, Jodrell DI, Tuveson DA, Fearon DT. Targeting CXCL12 from FAP-expressing carcinoma-associated fibroblasts synergizes with anti-PD-L1 immunotherapy in pancreatic cancer. Proc Natl Acad Sci USA, 2013 110: 20212-20217.

104. Obermajer N, Wong JL, Edwards RP, Odunsi K, Moysich K, Kalinski P. PGE(2)driven induction and maintenance of cancer-associated myeloid-derived suppressor cells. Immunol Invest, 2012 41: 635-657.

105. Liberman J, Sartelet $H$, Flahaut M, Mühlethaler-Mottet $A$, Coulon A, Nyalendo C, Vassal G, Joseph J-M, Gross N. Involvement of the CXCR7/CXCR4/CXCL12 axis in the malignant progression of human neuroblastoma. PLoS ONE, 2012 7: e43665.

106. Mühlethaler-Mottet A, Liberman J, Ascenção K, Flahaut M, Balmas Bourloud K, 
Yan P, Jauquier N, Gross N, Joseph J-M. The CXCR4/CXCR7/CXCL12 Axis Is Involved in a Secondary but Complex Control of Neuroblastoma Metastatic Cell Homing. PLoS ONE, 2015 10: e0125616.

107. Danielli R, Patuzzo R, Ruffini PA, Maurichi A, Giovannoni L, Elia G, Neri D, Santinami M. Armed antibodies for cancer treatment: a promising tool in a changing era. Cancer Immunol Immunother, 2015 64: 113-121.

108. Johannsen M, Spitaleri G, Curigliano G, Roigas J, Weikert S, Kempkensteffen C, Roemer A, Kloeters C, Rogalla P, Pecher G, Miller K, Berndt A, Kosmehl H, Trachsel E, Kaspar M, Lovato V, González-Iglesias R, Giovannoni L, Menssen HD, Neri D, de Braud F. The tumour-targeting human L19-IL2 immunocytokine: preclinical safety studies, phase I clinical trial in patients with solid tumours and expansion into patients with advanced renal cell carcinoma. Eur J Cancer, 2010 46: 2926-2935.

109. Shusterman S, London WB, Gillies SD, Hank JA, Voss SD, Seeger RC, Reynolds CP, Kimball J, Albertini MR, Wagner B, Gan J, Eickhoff J, Desantes KB, Cohn SL, Hecht T, Gadbaw B, Reisfeld RA, Maris JM, Sondel PM. Antitumor Activity of Hu14.18-IL2 in Patients With Relapsed/Refractory Neuroblastoma: A Children's Oncology Group (COG) Phase II Study. Journal of Clinical Oncology, 201028 : 4969-4975.

110. Najjar YG, Finke JH. Clinical perspectives on targeting of myeloid derived suppressor cells in the treatment of cancer. Front Oncol, 2013 3: 49.

111. Kumar V, Patel S, Tcyganov E, Gabrilovich DI. The Nature of Myeloid-Derived Suppressor Cells in the Tumor Microenvironment. Trends in immunology, 2016 37: 208-220.

112. Postow MA, Chesney J, Pavlick AC, Robert C, Grossmann K, McDermott D, Linette GP, Meyer N, Giguere JK, Agarwala SS, Shaheen M, Ernstoff MS, Minor D, Salama AK, Taylor M, Ott PA, Rollin LM, Horak C, Gagnier P, Wolchok JD, Hodi FS. Nivolumab and Ipilimumab versus Ipilimumab in Untreated Melanoma. N Engl J Med, 2015.

113. Sharma $P$, Allison JP. The future of immune checkpoint therapy. Science, 2015 348: 56-61.

114. Long AH, Highfill SL, Cui Y, Smith JP, Walker AJ, Ramakrishna S, El-Etriby R, Galli S, Tsokos MG, Orentas RJ, Mackall CL. Reduction of MDSCs with All-trans Retinoic Acid Improves CAR Therapy Efficacy for Sarcomas. Cancer Immunol Res, 2016 4: 869-880.

115. Shrimali RK, Yu Z, Theoret MR, Chinnasamy D, Restifo NP, Rosenberg SA. Antiangiogenic agents can increase lymphocyte infiltration into tumor and enhance the effectiveness of adoptive immunotherapy of cancer. Cancer Res, 2010 70: 61716180.

116. Moen I, Stuhr LEB. Hyperbaric oxygen therapy and cancer--a review. Target Oncol, 2012 7: 233-242.

117. Hu-Lieskovan S, Mok S, Homet Moreno B, Tsoi J, Robert L, Goedert L, Pinheiro EM, Koya RC, Graeber TG, Comin-Anduix B, Ribas A. Improved antitumor activity of immunotherapy with BRAF and MEK inhibitors in BRAF(V600E) melanoma. Sci 
Transl Med, 2015 7: 279ra41-279ra41.

118. Orentas RJ, Lee DW, Mackall C. Immunotherapy targets in pediatric cancer. Front Oncol, 2012 2: 3.

119. Orentas RJ, Yang JJ, Wen X, Wei JS, Mackall CL, Khan J. Identification of cell surface proteins as potential immunotherapy targets in 12 pediatric cancers. Front Oncol, 2012 2: 194. 